\title{
Sexuality: Homosexual and Heterosexual Conceptions in the Selected Poems of Walt Whitman
}

\author{
Kimberth D. Obeso ${ }^{1} \&$ Genebelle C. Bargamento ${ }^{2} \&$ Febby D. Lavador $^{3}$ \\ ${ }^{1,2,3}$ College of Arts and Sciences, Cebu Normal University, Cebu City, Philippines, 6000 \\ Correspondence: Kimberth D. Obeso, Cebu Normal University, Cebu City, Philippines. \\ Email: kimberthobeso@gmail.com
}

DOI: $10.53103 /$ cjlls.v1i2.15

\begin{abstract}
This literary research aims to analyze the selected poems of Walt Whitman: "Not Heat Flames Up and Consumes", "When I Heard at the Close of the Day", "A Woman Waits for Me", and "Spontaneous Me". This study assumes that the selected poems depict sexuality such as homosexual and heterosexual nuances. The text of the poems supporting the study's assumptions is descriptively analyzed based on archetypal theory and formalistic theories. This in-depth study further utilizes a qualitative method of discourse analysis in scrutinizing the representative poems. Findings revealed three phases: a) signifier and signified transaction; b) conceptualization of imagery; and c) author's insightful textual view. It is concluded that Walt Whitman's selected poems reveal homosexual and heterosexual manifestations.
\end{abstract}

Keywords: Homosexual, Heterosexual, Walt Whitman, Sexuality, Poetry

\section{Introduction}

Poetry is often defined as the rhythmic imaginative language expressing the poet's creative thought (Senatin \& Centera, 2003). In fact, critics make a clear-cut elaboration regarding the distinction between poetry and poem. Poetry refers to the artistic process and the offshoot of this process is a poem: an imaginative text. Poets accompanied by their respective masterpieces are widely studied by critics and researchers. Each poet has a distinctive style of writing. Others write by following a strict pattern while others do not. One of the poets in English literature is Walt Whitman.

Whitman initiates and popularizes in generating poems without specific measurements, known as free verse. That is why critics call him the father of verse. He is best known for his anthology: Leaves of Grass.

This anthology is published with several editions. For numerous years, Whitman's compilation of poems becomes part of the literary canon, not only in America but all over the world. According to the scholars who scrutinize the aforesaid masterpiece, the author is interested in writing about political concerns and the typical people as a whole 
(Edlun, 2017). More so, this poet is among those eminent bards who write poems about sexuality as the theme of their composition.

Sexuality refers to biological gender, gender identity, and gender role. Homosexuality is the performance of erotic activities with another of the same sex. Heterosexuality, on the contrary, refers to any amorous activities with another of the opposite sex. During the earlier times, the sex-gender classification was not of high interest of the cognoscenti, unlike today's generation. The heterosexual, on the other hand, is a term that is deemed normative from a societal standpoint. Nowadays, the aforementioned terms have become an acceptable expression due to liberal movements that are initiated by homosexual and heterosexual individuals. With societal acceptance, people get interested in the concepts of sexuality. Many writers, not only novelists and short story writers but also poets craft masterpieces with sexual insights in whatever ways of manifestation (Garcia, 2009). With the rise of the said concepts in the literary fields, individuals become fascinated by conducting a study concerning the author's masterpieces with homosexual and heterosexual motifs.

Furthermore, the goal of this literary investigation is to inspire scholars to get back and maintain their love for the analysis of poems. Another purpose of this study is to inspirit critics and enthusiasts to revive their love of criticizing poetry to be able to decode the hidden meaning of the text. Motivating educators and literature major students in searching poems for analysis is another aim of this study.

This literary study mainly analyzes Whitman's selected poems, by means of the formalistic and archetypal techniques of acquiring deeper insights into Walt Whitman's sexuality as manifested by his homosexual and heterosexual undertones. The prominence of the author is one of the reasons why this study is conceived. The author's innovative technique is another rational ground for conducting a study. The result of this research is hoped to give an imperative and remarkable contribution to individuals in the field of literary studies. Critics, researchers, enthusiasts, literature major students, and educators will benefit from this critical analysis, for it will serve as a reference in comprehending the poems of Walt Whitman. The offshoot of this thorough analytic exposition will further help pioneers in the field of gender research.

In connection with the said claim, in-depth discourse analysis is employed in order to arrive at the principal result. The research argument is supported by the formalistic theory and archetypal theory.

\section{Formalistic Approach and Archetypal Approach}

Critics using the formalistic theory adhere to the text itself. They are not taking into account outside influences such as the inclusion of the author's biography, the portrayal of reality, and the incorporation of the reader's personal reaction (Leitch, 2001). Formalist critics focus on the poetic elements to extract the signification from the text. On 
the other hand, the archetypal theory propounds the idea that humans have preconceived notions regarding symbolic motifs in one's milieu. In fact, this theory is postulated by Carl Jung. He believes and defines the term "collective unconscious" as something inherited from the unconscious mind which partakes by all constituents of the same race. This theorist further conceives that the human life cycle is honed by pattern and symbolic archetypes (Yap-Patron, 2002). For archetypal critics, things around us emblematize underlying meaning.

The discussion on the sexuality of Walt Whitman's poem is structural and symbolic and hence uses formalistic and archetypal approaches. In a wider scope, this comprehensive research is assumed to be a guide for literati on how to use the preferred theories in the analysis of literary works.

\section{Methodology}

This study uses a qualitative method of discourse analysis in investigating sexuality concerning homosexual and heterosexual conceptions of the selected poems of Walt Whitman. "Not Heat Flames Up and Consumes", "When I Heard at the Close of the Day" are analyzed according to sexual vantages that are pertinent to homosexual tendencies. The two remaining poems, "A Woman Waits for Me", and "Spontaneous Me" are interpreted according to sexual concepts that are related to heterosexual viewpoints. The close scrutiny of the poem is in accordance with the signifier and signified transaction, conceptualization of imagery, and author's insightful textual views. Discourse analyses as part of the qualitative method include the investigation of structures, that is, the presence of rhetorical devices and linguistic techniques (Richie \& Lewis, 2003).

The primary object of textual analysis is Walt Whitman's Leaves of Grass. The anthology used for this study is an electronic classic series which is edited by Jim Manis, a faculty member of the English Department of the Pennsylvania State University. Secondary sources are taken from reviews, books, theses, dissertations, and journals. Furthermore, this qualitative research follows the three fundamental analytical phases in order to arrive at the principal result: Phase 1. Signifier and Signified Transaction; Phase 2. Conceptualization of imagery; and Phase 3. Author's Insightful Textual Views.

Phase 1 shows the symbols that signify an underlying concept. Researchers analyze the selected stanzas and lines of the poems to extract related concepts concerning signifier and signified transactions in this phase.

Phase 2 presents the poetic images which are anchored on human sensation. In this phase, researchers investigate the selected stanzas and lines of the poems to reveal the conceptualization of imagery.

Phase 3 exhibits the tone and the diction of the text. In this phase, researchers decode the stanzas and lines to get related data regarding the author's insightful textual views. 


\section{Results and Discussion}

This section presents the results of the data analysis. The data gathered are processed in response to the subproblems presented in the preceding section in this critical investigation.

\section{Signifier and Signified Transaction}

\section{Homosexual Conceptions}

The poems under comprehensive study have numerous symbolic archetypes. These archetypes depict sexuality-related standpoints. Al-Nehar (2017) asserts that the essential societal concerns are illuminated out of the author's utilization of ingenious systematic symbols. Killingsworth (2001) goes on elaborating that Whitman employs archetypal emblems which are family-related concepts. In Kolbe's (2009) words, these symbols somehow mirror the personal life of the author.

In a textual analysis, López Peña (2014) goes on elaborating that the Calamus cluster intensifies the concept of human sexuality, eroticism, and democracy. She further asserts that the male attachment provokes a liberal poetic goal.

The first poem "Not Heat Flames Up and Consumes" has nature symbolic archetypes. The first line, the title of this poem, delineates the ardent emotion of the persona. As Ferber (1999) puts it, flame signifies love and passion. Heat, in addition, represents sensual desire (Cirlot, 1971). Prior to the persona's saddened emotion, he is in love and at the same time sexually attracted to his male partner. The persona implies the distress of getting into a relationship. The persona even compares his desires and thoughts to the natural phenomena as described in this passage: "Not sea-waves hurry in and out" (Whitman, 2013, p. 146). The sea symbolizes the unconscious thought of the persona. It is not consciously done by the persona to feel empty on their relationship. In a qualitative investigation of the select poem of Walt Whitman, Green (1996) infers that this poem deals with manly love or homosexual affection. This poem further adheres to the sensual bedfellows who value the erotic spectrum.

The symbolic archetype can also be found in this line: "Not the air delicious and dry, the air of ripe summer, bears lightly along white down-balls of myriads of seeds" (Whitman, 2013, p.146). Summer stands for maturity in this line (Ferber, 1999); whereas, air signifies freedom. It reflects on the persona's bearing. Because of emotional distress, he chooses to voice out what he feels by accentuating the danger of getting into a relationship. He yearns to be free and mature enough to handle every situation between him and his lover. Their relationship is about to end or die. Some critics are bewildered regarding the interconnection of coupling and demise. Erkkila (2011) asserts that the symbolic death echoes to the persona's sexuality and physical self. 
The second poem "When I Heard at the Close of the Day," has nature and set symbolic archetypes. "Not Heat Flames Up and Consumes", and "When I Heard at the Close of the Day" are part of the "Calamus" cluster. The title is derived from the Calamus plants which portray sexual symbolism. On a related note, Al-Nehar (2017) declares that the physical features of this anthology are considered phallic signification. This poem is, in fact, originally part of the "Live Oak, with Moss" poetic compilation and is revised into new edition: Calamus. Critics grant that "Live Oak, with Moss" as a homosexual manifesto (Scholnick, 2004). It adheres to gay standpoints which are erotic and affectionate (Erkkila, 2011).

The nature symbols, on the other hand, are dominant emblems in this poem. In fact, this poem exhibits the persona's expectation of obtainment as vividly described: "When I heard at the close of the day how my name had been receiv' $d$ with plaudits in the capitol, still it was not a happy night for me that followed" (Whitman, 2013, p. 143). The day is a symbolism of hope (Hancock, 1972; Chevalier \& Gheerbrant, 1996). In this line, the persona is unsatisfied even though he achieves something in his life because his male lover is not by his side. Notwithstanding, he is hopeful that he will see his lover again. The homosexual viewpoints are evident in these lines: "When I wandered alone over the beach, and undressing bathed, laughing with the cool waters, and saw the sunrise, /And when I thought how my dear friend my lover was on his way coming, O then I was happy" (Whitman, 2013, p. 143). Water signifies cleansing while sunrise emblematizes a new beginning (Hancock, 1972; Chevalier \& Gheerbrant, 1996). The persona is now satisfied and wanted to discard all his pessimistic emotions because his lover is on his way coming. The persona also realizes and deems that their romantic relationship is a sign of novel commencement. The set symbol is exemplified in this line: "But the day when I rose at dawn from the bed of perfect health, refreshed, singing, inhaling the ripe breath of autumn" (Whitman, 2013, p. 143). The bed represents the exploited matrimony (Hancock, 1972; Chevalier \& Gheerbrant, 1996). The lovers of the same sex are united to carry on their romantic amorous relationship.

\section{Heterosexual Conceptions}

The third poem "A Woman Waits for Me" has these following symbolic archetypes: human body part, nature, and action. The first nature and human body part symbolic archetypes are vividly illustrated in this line: "They are tann'd in the face by shining suns and blowing winds" (Whitman, 2013, p.177). This line reduces women whom the persona encounters. Face embodies identity. It shows women's capability that is equated to that of men. Sun signifies masculinity (Hancock, 1972; Chevalier \& Gheerbrant, 1996); whereas, wind symbolizes violent emotion (Ferber, 1999). Women are likened to men who have ferocious feelings. 
The nature symbols carry on in the succeeding line: "Through you, I drain the pentup rivers of myself" (Whitman, 2013, p. 118). River emblematizes fertility (Cirlot, 1971). This line evokes the potentiality of the persona to produce young children through the coupling. The desire for propagation is further demonstrated in this line: "I shall count on the fruits of the gushing showers of them, as I count on the fruits of the gushing showers I give now" (Whitman, 2013, p. 118). Cirlot insists that fruit is a representation of fertility and carnal craving (1971). Fruit also symbolizes temptation and pleasure. The persona is lured by the gorgeousness of his woman lover. He wants to produce a child and thereby gains pleasure out of their lovemaking. Some critics assert that this poem uncloaks womanly aspects. Brown points out that the relative echelons of women and their freedom are almost disremembered in this poem (1991). Women are somewhat treated as the tool for procreation as stated in these lines: "They refuse to awake at the touch of any man but me/It is I, you women-I make my way" (Whitman, 2013, pp. 117-118). Touch emblematizes the sensual desire of the man. The woman becomes submissive to the persona.

The fourth and last poem, "Spontaneous Me" has numerous nature and color symbolic archetypes. This poem retains the sensual motif. It, in fact, evokes patriarchal supremacy and sexuality (Brown, 1991). Whitman equates the persona's desire for procreation to nature. He utilizes the freewheeling nature to create an analogy. The persona deems sex as a typical deed for humans, and thus it is a natural act to carry out. In line 4, the persona describes nature and associates it with his woman partner as demonstrated in this line: "The hillside whitened with blossoms of the mountain ash" (Whitman, 2013, p.119). Ferber declares that blossom signifies a woman's beauty and gentleness (1999). The persona is attracted to the physical features of his inamorata. Mountain in this line symbolizes stability (Hancock, 1972; Chevalier \& Gheerbrant, 1996). Their desire for propagation is not easily altered. Their emotions are further portrayed using colors as described in this line: "The same late in autumn, the hues of red, yellow, drab, purple, and light and dark green" (Whitman, 2013, p.119). This line depicts visual perception. Red is a representation of love, desire and "tearing emotion" (Cirlot, 1971). Out of engrossing affection, the persona develops sexual desire with his partner in order to father a child. Yellow, in addition, signifies happiness and hope (Hancock, 1972; Chevalier \& Gheerbrant, 1996). The persona supposes that their relationship will be delightful and auspicious. Further, purple represents mysteriousness. Their relationship is difficult to comprehend but what is essential is that they are united to bring forth offspring. Green symbolizes fertility (Hancock, 1972; Chevalier \& Gheerbrant, 1996). The persona is, therefore, a sexually inclined person who desires sex in order to yield a child. Drab symbolizes humility. The persona remains a down-to-earth person who treasures love and kindness as essential human values. 
More so, the craving for procreation manifests in this line: "The rich coverlet of the grass, animals, and birds, the private untrimm'd bank, the primitive apples, the pebblestones" (Whitman, 2013, 119). This line evokes sexual desire. Whitman mentions "coverlet" which means the cover of the bed. Apple in this line emblematizes temptation and sensual affection (Ferber, 1999). The persona is tempted; however, he is not ashamed of his endeavor and demeanor because he deems coupling as a natural act in order to produce offspring.

\section{Conceptualization of Imagery}

\section{Homosexual Conceptions}

There are numerous images in the selected poems. Whitman utilizes imagery as a technique to illustrate the sexual desire and affection of the persona. Whitman's poems feature images concerning freedom, fellowship, body, and coition. His anthology, in fact, is revised again and again for many years. The earlier edition is narrowed down due to the conflicting issues regarding sexuality. Nevertheless, Kolbe (2009) reasons that the social, political, and religious aspects remain unaltered. In "Maslan, Mark. Whitman Possessed: Poetry, Sexuality, and Popular Authority," Thomas (1983) deduces that critic's critical scrutiny typically adheres to the synthesis of the political and erotic concerns of Whitman's poem.

The persona of the poems in the Calamus cluster is a sexually inclined homosexual man. Sexuality is the state of being endowed with the appetite of the flesh. Sexual activity requires muscle sense. The poem's dominant type of imagery is kinesthetic (muscle sense). The imagery of visual, aural, thermal and olfactory can also be found in the representative poems. Aspiz (1987) suggests that critics of Whitman must look into the images about sexual gratification and eroticism in his poems.

The first poem "Not Heat Flames Up and Consumes" evokes deeply felt sensual craving of the persona. In a qualitative investigation of the Calamus sequence, Schweda (1973) perceives the dichotomy of the symbolic transaction of things, poetic images, and thematic elements of this cluster. Erotic images are illustrated in this poem. This is evident out of citing the nature-related terms which show the arduous affection of the homosexual couple. These images are Whitman's technique of homogenizing the persona's eroticism (Erkkila, 2011).

This poem contains kinesthetic imagery. This is evident in these lines: "Wafted, sailing gracefully, to drop where they may; / Not these, O none of these more than the flames of me, consuming, burning for his love whom I love, / O none more than I hurrying in and out" (Whitman, 2013, p.146). These lines delineate the persona's heavyhearted relationship with his male lover. He reminisces and deems his lover's deed including their sexual act. The persona shows well established feelings with his lover. He ends up reminding his lover and other individuals about the danger of getting into a romantic 
attachment. In fact, the literary, homosexual, and sexual dimensions in Whitman's poems propagate locally and globally because of his desire to make his works available to his partner and comrade.

The second poem "When I heard at the Close of the Day" has the imagery of aural and kinesthetic. Whitman (2013) writes: "And that night while all was still, I heard the waters roll slowly continually up the shores/I heard the hissing rustle of the liquid and sands as directed to me whispering to congratulate me" (p.143). Aural imagery predominates in these lines. The persona of this poem is already satisfied and delighted because he already sees his lover. These lines, in addition, evoke the pacific mental and emotional state of the persona. The auditory image is delineated out of citing acoustical words such as "whispering" and "hissing." Out of these imageries, the sensual coupling is highlighted.

As part of the Calamus cluster, this poem celebrates the bodily desire and sex act which are depicted through kinesthetic images: "touching, hugging, pressing, kissing, and sleeping together" (Erkkila, 2011). The kinesthetic and thermal imagery can also be found in this poem as lucidly described in these lines: "For the one, I love most lay sleeping by me under the same cover in the cool night, /In the stillness in the autumn moonbeams his face was inclined toward me, /And his arm lay lightly around my breast - and that night I was happy" (Whitman, 2013, p. 143). The man is now tranquil and free from anxiety because his lover is now with him. These lines also delineate the persona's sexual intercourse with his male partner. Whitman, in fact, alters some lines which are sensual and straightforward. Nevertheless, the alteration does not decimate the sensual content of the poem.

\section{Heterosexual Conceptions}

The third poem "A Woman Waits for Me" contains visual and kinesthetic images; however, the dominant imagery in this poem is kinesthetic. This poem is part of the "Children of Adam" cluster. Furthermore, stimulating images are used in this poetic series which highlight the commendation of coupling (Oliver, 2006). Further, Brown (1991) declares that this cluster has sensual imagery and thereby illuminates masculinity and sexuality. This cluster celebrates the images of a man who enjoys copulation with a woman for procreation. The bodily desire, lust, and emotiveness are therefore emphasized through these images. Critics posit that the womanly concepts are given signification; however, the "Adamic" persona remains the paramount imagery in this poem. Erkkila (2011) concludes that this poem magnifies manly sexuality and coition between persons of the opposite sex.

Kinesthetic imagery is shown in these lines: "Without shame, the man I like knows and avows the deliciousness of his sex/without shame the woman I like knows and avows hers" (Whitman, 2013, p. 117). The two individuals are swapping oath. These lines depict the carnal commitment of the couple. The imagery of kinesthetic persists in these lines: "I pour the stuff to start sons and daughters fit for These States-I press with slow rude 
muscle,/I brace myself effectually-I listen to no entreaties,/I dare not withdraw till I deposit what has so long accumulated within" (Whitman, 2013, p. 118). The persona wants to produce offspring through coitus. These lines elaborate the persona's strong determination and willingness to stand whatever is the consequence of their sensual deeds. The bardic line "dare not withdraw till I deposit" evokes sexual activity or coitus between a man and a woman. The man's genitalia, on the other hand, is not withdrawn during copulation because he wants to yield children.

The desire for procreation is portrayed in the succeeding stanzas: "The drops I distal upon you shall grow fierce and athletic girls, new artists, musicians, and singers,/The babes I beget upon you are to beget babes in their turn,/I shall demand perfect men and women out of my love-spendings" (Whitman, 2013, p. 118). In these lines, the persona foretells the forthcoming events after their sex act. The persona further conceives that his genetic state will give birth to gifted children through their lovemaking. The imagery of visual is evident in stanzas 2-4: "All the governments, judges, gods, follow'd persons of the earth...I see that they understand me, and do not deny me/ I see that they are worthy of me-I will be the robust husband of those women" (Whitman, 2013, p.117). These lines elucidate the inclusion and parameter of sex. These also exhibit the persona's commitment to a harmonious relationship.

The fourth poem "Spontaneous Me" portrays visual, olfactory, and kinesthetic images. Brown (1991) reasons that critics perceive masculine images in this poem which portrays patriarchal viewpoints. The imagery of visual which makes the readers envisage an appreciative and picturesque concept is lucidly illustrated in these lines: "The hillside whitened with blossoms of the mountain ash,/The same late in autumn, the hues of red, yellow, drab, purple, and light and dark green,/The rich coverlet of the grass, animals and birds, the private untrimmed bank, the primitive apples, the pebble-stones" (Whitman, 2013, p. 119). The persona espies and compliments the natural scenery.

Kinesthetic imagery is evident in this line: "The hairy wild-bee that murmurs and hankers up and down, that gripes the full-grown lady-flower, curves upon her with amorous firm legs, takes his will of her, and holds himself tremulous and tight till he is satisfied" (Whitman, 2013, p. 119). This line evokes the sexual activity of creatures. The bee clings to the bloom in order to yield more flowers. Akin to the creature's sensual exertion, the persona engages in copulation in order to produce offspring as clearly stated in this line: "Two sleepers at night lying close together as they sleep, one with an arm slanting down across and below the waist of the other" (Whitman, 2013, p.119). Kinesthetic imagery can also be found in these lines: "The young man that flushes and flushes, and the young woman that flushes and flushes, /The young man that wakes deep at night, the hot hand seeking to repress what would master him" (Whitman, 2013, p.120). These lines evoke the sexual activity of the persona along with his partner. The two individuals are flushing either in shame or excitement. Olfactory imagery is manifested in this line: "The smell of apples, 
aromas from crushed sage-plant, mint, birch-bark" (Whitman, 2013, p.119). This reduces sweet redolent coitus.

\section{Author's Insightful Textual Views}

\section{Homosexual Conceptions}

Most of the representative poems that have been cited in the author's insightful textual views concerning homosexual conceptions have almost similar diction and tone. These dictions and tones generate and show sexuality-related viewpoints. Warren (1990) claims that the poems of Walt Whitman adhere on the concept of mystery, artistry, and sexuality.

The first poem, "Not Heat Flames Up and Consumes" has informal diction. This is evident in this line: "Not these, $\mathrm{O}$ none of these more than the flames of me, consuming, burning for his love whom I love" (Whitman, 2013, p. 146). The usage of the subjective pronoun "I" and "me" makes this poem informal. The "I" also portrays a personal tone that echoes the identity of the author. Killingsworth (2001) reasons that critics of Whitman assert that his anthology is somewhat written in confessional style expressing his own identification and sensuality. It has also vulgar diction. "Ball" is mentioned in the poem. This is a vulgar term for testis. Tuten (1992) contends that Whitman's diction influences some scholars for his effective use of sensual lingo in his poem. Its diction provokes homosexual or gay concepts. The gay term portrays gender identification which is embedded in the structure of this poem.

Moreover, this poem has a serious and assertive tone, as manifested in this line: "Not these, $\mathrm{O}$ none of these more than the flames of me, consuming, burning for his love whom I love" (Whitman, 2013, p.146). Helms goes on elaborating that this poem implies endangerment of getting into affinity and crestfallenness of manly romantic attachment (1992).

The third poem "When I heard at the Close of the Day," has informal diction. This is lucidly stated in this line: "And else when I carous'd, or when my plans were accomplish'd still I was not happy," (Whitman, 2013, p.143). The usage of subjective pronoun "I" and "my" makes this poem informal. Out of the informal diction, the personal tone is illuminated. Another factor which makes this poem informal is the inclusion of the contracted words such as "carous'd" and "accomplish'd." What is fascinating in Walt Whitman's poem is the incorporation of conjugated and shortened words; and hence, portraying linguistic distinction. His poetic phraseologies flaunt comradeship, manly love, historical accounts, scientific adherence, body, and soul. Erkkila (2011) claims that these dictions depict the language of the proletariat who delineate homosexual affection. The persona in this poem certifies his own mighty affection and camaraderie among other people (Schweda, 1973). 
The poem has dramatic and sensual tones. The dramatic tone runs throughout the text. The persona is dissatisfied without his lover. This is evident in this line: "And when I thought how my dear friend my lover was on his way coming, O then I was happy" (Whitman, 2013, p.143). The persona wants to sleep together with his partner in one bed and thus making this poem sensual as clearly illustrated in this line: "For the one I love most lay sleeping by me under the same cover in the cool night" (Whitman, 2013, p. 143).

\section{Heterosexual Conceptions}

The third poem "A Woman Waits for Me" has informal diction. The informal diction manifests in these lines: "They are not one jot less than I am / They are tann'd in the face by shining suns and blowing winds" (Whitman, 2013, p.117). The utilization of nominative pronoun "I" and the inclusion of shortened words like "tann' $d$ " make this poem informal. The informality, on the other hand, makes the poem more realistic and casual. The usage of "I" also carries out personal tone efficiently.

This poem has also slang diction. This is limpidly demonstrated in this line: "The babes I beget upon you are to beget babes in their turn" (Whitman, 2013, p. 118). The "babes" term is reiterated and meant a juvenile woman who is sexually attractive.

The poem has a procreative and amorous tones. This is clearly illustrated in these lines: "These States - I press with slow rude muscle, / I brace myself effectually-I listen to no entreaties, /I dare not withdraw till I deposit what has so long accumulated within me" (Whitman, 2013, p. 118). The persona's desire for propagation is reflected in these lines. He believes that he can only attain this through copulation with a woman. Schweda (1973) argues that in the first part of this poem, there is anticipating tone of engagement; however, it gradually alters into the previsioning tone of journeying in the succeeding lines.

The fourth poem "Spontaneous Me," has informal diction as clearly exemplified in these lines: "The loving day, the mounting sun, the friend I am happy with/The arm of my friend hanging idly over my shoulder/The hillside whiten'd with blossoms of the mountain ash" (Whitman, 2013, p. 119). The nominative pronoun "I" and the pronominal adjective "my" make this poem informal and personal. The contracted words also produce a casual remark about the persona's thoughts and feelings. For Brown (1991), this poem evokes the persona's sexual gratification and desire for procreation.

Furthermore, this poem has a slang diction. This is evident in this personified passage: "The greed that eats me day and night with hungry gnaw, till I saturate what shall produce boys to fill my place when I am through" (Whitman, 2013, p.120). The term "eat" in this line is exploited vulgarly. This word connotes cunnilingus: oral stimulation of the woman's genital. Slang term can also be found in this line: "The oath of procreation I have sworn, my Adamic and fresh daughters" (Whitman, 2013, p. 120). The "fresh" in this line is a slang term for fashionable. 
The poem, in addition, has a randy tone. The persona in this poem is sexually excited as described in this line: "The body of my love, the body of the woman I love, the body of the man, the body of the earth" (Whitman, 2013, p. 119). The persona's desire for copulation makes this poem libidinous. The persona also accepts that sex is natural for every couple. He is a man with a driven need for coupling.

This literary research is focused on the analysis of Walt Whitman's selected poems adhering to the signifier and signified transaction, conceptualization of imagery, and author's insightful textual views. The representative poems are chosen because of their polemical vantage points.

The thorough investigation presented above is limited to Walt Whitman's poems ("Not Heat Flames Up and Consumes", "When I heard at the Close of the Day", "A Woman Waits for Me", and "Spontaneous Me") with their formalistic and archetypal concepts as parameter of the qualitative investigation.

\section{Conclusion}

Based on the formalistic and archetypal analysis on Walt Whitman's selected poems, the following findings are hereby represented: a.) the signifier and signified transaction is filled with symbolic archetypes which are erotic and amorous; b) the conceptualization of imagery delineates images related to romantic attachment, coitus and eroticism; and c) the author's insightful textual view depicts the vocabulary and phraseology of the homosexual and heterosexual individuals. It is also found out that Walt Whitman's selected poems have symbolic motifs concerning nature, human body part, action, set, and color. The study further discloses that the representative poems have images that are generated by the olfactory, kinesthetic, aural, thermal, and visual sensation. The preponderant dictions of the studied poems are informal, slang, and vulgar. Lastly, the poems show provocative, personal, and sensual tones. The study concludes that the selected poems reveal sexuality regarding homosexual and heterosexual conceptions. It is therefore recommended that the result of this thorough qualitative investigation be used by literary researchers, critics, educators, literature major students, and enthusiasts as their reference in an interactive discussion and in a literary scrutiny of Whitman's poems.

\section{Acknowledgment}

First and foremost, we are extremely grateful to our adviser, Dr. Lito Diones for his continuous support, invaluable advice, and patience during our undergraduate study. Thank you for the effort expended in making this research possible. Our gratitude extends to Dr. Niña Jen Ruta-Canayong and Dr. Reynaldo Caturza for their support which was influential in inspiring and honing our capabilities as literary researchers. Lastly, we would like to thank all the ESOL educators for patiently and graciously supplying us with wisdom. 


\section{References}

Al-Nehar, A. E. (2017). Whitman's "Song of Myself" "The Structure of Song of Myself". Arab Journal of Sciences \& Research Publishing, 193-204.

Aspiz, H. (1987). Sexuality and the language of transcendence. Walt Whitman Quarterly Review, (5) 2, 1-7.

Brown, B.D. (1991). Whitma's failures: "Children of Adam" in the light of feminist ideals (Published Master's thesis). University of North Texas.

Cirlot, J.E. (1971). A dictionary of symbols. Routledge and Kegan Pau Ltd.

Chevalier, J., \& Gheerbrant, A. (1996). The penguin dictionary of symbols. New York: Penguin

Erkkila, B. (2011). Walt Whitman's songs of male intimacy and love. United States of America: University of Iowa Press.

Ferber, M. (1999). A dictionary of literary symbols. The Edinburgh Building, Cambridge, UK: Cambridge University Press.

Garcia, N. (2009). Philippine gay culture. Hong Kong: Hong Kong University Press.

Green, C. B. (1996) "Calamus, drum-taps, and Whitman's model of comradeship (Published Research). The College of William and Mary in Virginia. Retrieved from https://dx.doi.org/doi:10.21220/s261z8-wk77

Hancock, E. (1972). Techniques for understanding literature. Belmont: CA.

Helms, A. (1992). Whitman's live oak with moss. The continuing presence of Walt Whitman. Ed. Robert K. Martin. Iowa City: U of Iowa.

Killingsworth, M. J. (2001). Pollak, Vivian R. The Erotic Whitman [review]. Walt Whitman Quarterly Review, 19, 52-55. Retrieved from https://doi.org/10.13008/21533695.1667

Leitch, V.B. (2001). The Norton anthology of theory and criticism. W. W. Norton \& Company, Inc.

Kolbe, B. (2009). Walt Whitman's split poetic personalities (Published Dissertation). Graduate School of Arts and Sciences Brandeis University.

López Peña, L. (2014). Dressing uncivil neighbor(hood)s. Walt Whitman's adhesive democracy in 'Calamus' and 'Drum-Taps. Lectora, 20, 61-80.

Oliver, C. (2006). Walt Whitman, a literary reference his life and work. New York: Facts on File, Inc.

Scholnick, R. J. (2004). "The texts and contexts of "Calamus": Did Whitman censor himself in 1860? Walt Whitman Quarterly Review (21). Retrieved from https://doi.org/10.13008/2153

Senatin, R., \& Centenera, F.G. (2003). Introduction to literature English 104. Mandaluyong City: National Book Store.

Schweda, D. N. (1973). The journey and the voyage motif in selected major poems, clusters, and short lyrics of the final edition (1891-92) of Walt |Whitman's Whitman's leaves of grass (Published Dissertation) Loyola University.

Tuten, N. L. (1992). The language of sexuality: Walt Whitman and Galway Kinnell. Walt Whitman Quarterly Review, 9, 134-141.

Thomas, M. W. (1983). Whitman's achievements in the personal style in Calamus. Walt Whitman Quarterly Review, (1) 36. Retrieved from 
https://doi.org/10.13008/2153 3695.1032

Warren, J. P. (1990). Walt Whitman's "Song of Myself": A mosaic of interpretations [review]. Walt Whitman Quarterly Review, 7, 141-143.

Whitman, W. (2013). Leaves of grass (Manis, J, Ed.). The Electronic Classic Series.

Yap-Patron, I. (2002). Interactive reading responding to writing about Philippine literature. Great Books Reading. 